\title{
Plant Disease Resistance Inducing Activity of 7-Oxo- and 7-Hydroxysterols
}

\author{
H. Schabdach ${ }^{\mathrm{a}}$, S. Johne ${ }^{\mathrm{c}}$, U. Steiner ${ }^{\mathrm{b}}$ and K. Seifert ${ }^{\mathrm{a}}$
}

a Lehrstuhl für Organische Chemie I/2, NW II, Universität Bayreuth, D-95440 Bayreuth, Bundesrepublik Deutschland

b Institut für Pflanzenkrankheiten und Pflanzenschutz, Universität Hannover, Herrenhäuser Str. 2, D-30419 Hannover, Bundesrepublik Deutschland

c Firma Ingenieurgesellschaft Wasser- und Tiefbau m.b.H. Bitterfeld, Zörbiger Str., D-06749 Bitterfeld, Bundesrepublik Deutschland

Z. Naturforsch. 50c, 257-262 (1995); received September 7/December 8, 1994

Dedicated to Professor Manfred Hesse on the occasion of his 60th birthday

Hordeum vulgare, Triticum aestivum, Poaceae, 7-Oxo and 7-Hydroxysterols, Induced Resistance

The 7-oxosterols 1-2 and the 7-hydroxysterols 3-6 induce resistance toward the fungal pathogens Puccinia striiformis West. and Puccinia hordei Otth in barley and wheat. Primary leaves of the plants were sprayed with solutions of the compounds $\left(10^{-4} \mathrm{~mol} / 1\right.$ in $1 \%$ aqu. ethanol) followed, 2 days later, by challenge inoculation with the fungal pathogens. The results indicate that $7 \alpha$ - and $7 \beta$-hydroxylated epimers of $\beta$-sitosterol and cholesterol show the highest value of induced resistance (39-49\% reduction of infection sites). No enhanced resistance toward the fungi Erysiphe graminis DC f. sp. tritici and hordei and Cochliobolus sativus Ito \& Kuribayashi was observed.

\section{Introduction}

The enhancement of resistance of otherwise susceptible host plants by prior infections or by treating them with chemicals without alterations in the genome is termed induced resistance (Schönbeck et al., 1993). Since Chester (1933) published the first review on this phenomenon numerous publications with different host-parasite systems have proven the efficiency of this type of protection against diseases caused by viruses, bacteria and fungi (Horsfall and Cowling, 1980; Kuc, 1987; Hammerschmidt, 1993). Induced resistance is distinguished from conventional chemical as well as biological procedures in plant protection by lack of toxicity of the inducing agents towards the pathogens, but depends on the stimulation of latent defence mechanisms of the plants. Although a number of resistance-inducing chemicals like salicylic acid (Mills and Wood, 1984), probeconazole (Sekizawa and Mase, 1981), isonicotinic acid (Kunz et al., 1988), fatty acids (Cohen et al., 1991) or metabolites of plants (Doubrava, 1988; Herger et al., 1988) and microorganisms (Schönbeck et al.,

Reprint requests to Prof. Dr. K. Seifert.

Telefax: (0921) 552671.
1981) are known, induced resistance is hardly used for the control of plant diseases until now (Sequeira, 1983; Steiner and Schönbeck, 1993)). Progress toward implementing this strategy has been limited by the availability of data concerning the efficiency and stability of induced resistance under natural infection pressure. Especially a broad spectrum of chemical compounds is missing which show activity in major crop plants like

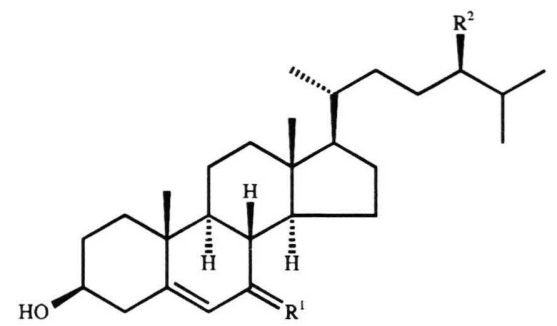

$$
\begin{array}{lll}
\mathbf{1} & \mathrm{R}^{1}=\mathrm{O} & \mathrm{R}^{2}=\mathrm{C}_{2} \mathrm{H}_{5} \\
\mathbf{2} & \mathrm{R}^{1}=\mathrm{O} & \mathrm{R}^{2}=\mathrm{H} \\
\mathbf{3} & \mathrm{R}^{1}=\beta-\mathrm{OH}, \alpha-\mathrm{H} & \mathrm{R}^{2}=\mathrm{C}_{2} \mathrm{H}_{5} \\
\mathbf{4} & \mathrm{R}^{1}=\beta-\mathrm{OH}, \alpha-\mathrm{H} & \mathrm{R}^{2}=\mathrm{H} \\
\mathbf{5} & \mathrm{R}^{1}=\alpha-\mathrm{OH}, \beta-\mathrm{H} & \mathrm{R}^{2}=\mathrm{C}_{2} \mathrm{H}_{5} \\
\mathbf{6} & \mathrm{R}^{1}=\alpha-\mathrm{OH}, \beta-\mathrm{H} & \mathrm{R}^{2}=\mathrm{H}
\end{array}
$$


monocots, induce resistance toward important pathogens as rust fungi, and can be applicated practically. Hofferek (unpublished results) and Reiss (1986) reported on induced resistance to Puccinia striiformis in barley (Hordeum vulgare L.), after spraying the primary leaves with the extract of roots or leaves from barley. From the root extract Seifert et al. (unpublished results) isolated 3 sterol compounds closely related to $\beta$-sitosterol, which induce resistance to Puccinia striiformis. The preformed bioactive compounds were determined as $3 \beta$-hydroxystigmast-5-en-7-one (1), stigmast-5-ene-3 $\beta, 7 \beta$-diol (3), and stigmast-5-ene$3 \beta, 7 \alpha$-diol (5).

In this paper we report on the resistance inducing activity of $\beta$-sitosterol and cholesterol derivatives bearing a carbonyl or a hydroxy group in position 7. Induced resistance caused by sterol derivatives, to our knowledge, has not been described so far. The induced resistance toward rust fungi in barley and wheat was evident as impaired success of the fungal pathogens in infecting the plants.

\section{Materials and Methods}

\section{Activity tests}

Barley plants (Hordeum vulgare L.) cv. 'Mammut' and wheat plants (Triticum aestivum L.) cv. 'Astron' were grown in commercial compost in a greenhouse controlled at $24{ }^{\circ} \mathrm{C} / 20{ }^{\circ} \mathrm{C}$ day /night temperature with $4 \mathrm{~h}$ supplementary lightning in the morning and evening to give a photoperiod of at least $16 \mathrm{~h}$ per day (light levels at plant height

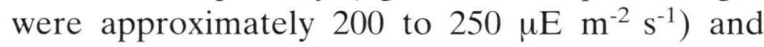
$65-80 \%$ rel. humidity. Inoculation experiments were carried out with 7-day-old seedlings using field isolates of the fungi Erysiphe graminis DC f. sp. tritici and hordei Em. Marchal, Puccinia striiformis West., P. hordei Otth and Cochliobolus sativus Ito \& Kuribayashi.

For fungitoxicity studies agar pieces $\left(1 \mathrm{~cm}^{2}\right)$ were coated with $20 \mu \mathrm{l}$ droplets of the $10^{-4} \mathrm{~mol} / \mathrm{l}$ water solutions ( $1 \%$ ethanolic) of the sterol derivatives 1-6 before the spores of the biotrophic fungi were applied. Conidia of powdery mildew were incubated for $24 \mathrm{~h}$ at $20^{\circ} \mathrm{C}$ in the darkness, the uredospores of the rusts at $100 \%$ rel. humidity at $15^{\circ} \mathrm{C}$ in the darkness on the agar in petri dishes. Spore germination and germ tube elongation of
100 spores per treatment were measured microscopically. The effects on C. sativus were studied in agar diffusion tests applying $20 \mu \mathrm{l}$ droplets of the $10^{-4} \mathrm{~mol} / \mathrm{l}$ sterol solutions and measuring the mycelium growth compared to $1 \%$ ethanol water solution controls after 5 days.

The sterol derivatives 1-6 were tested for their ability to induce disease resistance on intact plants. The compounds were formulated in $1 \%$ aqu. ethanol to give concentrations of $10^{-4} \mathrm{~mol} / \mathrm{l}$, $10^{-6} \mathrm{~mol} / \mathrm{l}$ and $10^{-9} \mathrm{~mol} / \mathrm{l}$ and sprayed on the lower and upper leaf surfaces of the primary leaves of 7-day-old plants with a hand held sprayer $(3-4 \mu \mathrm{l} /$ $\mathrm{cm}^{2}$ leaf). The plants were challenged with the pathogens immediately or two days after the application of the sterol derivatives. With the conidia from 10-day-old colonies of E. graminis f. sp. tritici or f. sp. hordei the wheat and barley plants were inoculated in an inoculation chamber at $20-22^{\circ} \mathrm{C}$. To inoculate the wheat plants with $P$. striiformis and barley plants with $P$. hordei they were sprayed with uredospore suspensions $(80.000$ spores $/ \mathrm{ml})$ of the fungi followed by an incubation period of $24 \mathrm{~h}$ in an infection tent in the dark at $15^{\circ} \mathrm{C}$ and high humidity. For the inoculation of $C$. sativus conidia suspensions $(80.000$ spores $/ \mathrm{ml})$ were used and the plants were maintained $48 \mathrm{~h}$ in the dark at high humidity at $20^{\circ} \mathrm{C}$. Plant disease severity was monitored by counting the infection sites 7 days after inoculation and the resistance inducing activity of the applicated sterole derivatives was calculated in $\%$ disease reduction compared to control plants. The experiments were repeated three times with 30 plants per treatment. Results given below represent mean values of the experiments. Means were compared employing the Student's t-test. Plants treated with $1 \%$ aqu. ethanol served as controls.

\section{Product analysis}

General

Mps: uncorr.. IR spectra were recorded on a Bio-Rad FTS-40 spectrometer. The mass spectra were measured on a Varian MAT-312 spectrometer and the ${ }^{1} \mathrm{H}-{ }^{13} \mathrm{C}$ NMR spectra on a Bruker AC-300 spectrometer. TLC on silica gel sheets (cyclohexane-EtOAc (1:1), .0.25 mm, Polygram R SILG/UV 254$)$. Spots were visualized by UV $(254 \mathrm{~nm})$ and spraying with 'Rosenheim reagent' 
(20 $\mathrm{g} \mathrm{SbCl}_{3}$ in $100 \mathrm{ml}$ of $\mathrm{CHCl}_{3}-\mathrm{HOAc}$ (3:1)) followed by heating at $110^{\circ} \mathrm{C}$. Column chromatography was performed on silica gel $60(0.063-0.2$ $\mathrm{mm})$ with cyclohexane-EtOAc $(1: 1)$.

$3 \beta$-Hydroxystigmast-5-en-7-one (1)

$\mathrm{R}_{\mathrm{f}}$ 0.38; m.p. $149-152{ }^{\circ} \mathrm{C}$; IR $v_{\max } \mathrm{CHCl}_{3} \mathrm{~cm}^{-1}$ : 3613(OH), 1667(C=O); MS $70 \mathrm{eV} \mathrm{m} / z$ (rel. int.): $428\left(\mathrm{M}^{+}, 100\right), 395$ (12); ${ }^{1} \mathrm{H}-\mathrm{NMR}\left(\mathrm{CDCl}_{3}\right) \delta$ (ppm): $0.65(3 \mathrm{H}, \mathrm{s}, \mathrm{H}-18), 0.78(3 \mathrm{H}, \mathrm{d}, J=6.7 \mathrm{~Hz}$, $\mathrm{H}-26), 0.80(3 \mathrm{H}, \mathrm{d}, J=6.7 \mathrm{~Hz}, \mathrm{H}-27), 0.81(3 \mathrm{H}, \mathrm{m}$, $\mathrm{H}-29), 0.90(3 \mathrm{H}, \mathrm{d}, J=6.5 \mathrm{~Hz}, \mathrm{H}-21), 1.16(3 \mathrm{H}, \mathrm{s}$, $\mathrm{H}-19), 2.20(1 \mathrm{H}, \mathrm{dd}, J=10.6 \mathrm{~Hz}, \mathrm{H}-8), 3.65(1 \mathrm{H}$, $\mathrm{m}, \mathrm{H}-3 \alpha), 5.65(1 \mathrm{H}, J=1.5 \mathrm{~Hz}, \mathrm{H}-6) ;{ }^{13} \mathrm{C} \mathrm{NMR}$ : see Table I.

3ß-Hydroxycholest-5-en-7-one (2)

$\mathrm{R}_{\mathrm{f}}$ 0.36; m.p. $169-170{ }^{\circ} \mathrm{C}$; ref. (Chicoye et al., 1968) m.p. $172{ }^{\circ} \mathrm{C}$; IR $v_{\max } \mathrm{CHCl}_{3} \mathrm{~cm}^{-1}: 3609(\mathrm{OH})$, 1667(C=O); MS $70 \mathrm{eV} \mathrm{m} / z$ (rel. int.): $400\left(\mathrm{M}^{+}\right.$, 100), 368 (14); ${ }^{1} \mathrm{H}$ NMR $\left(\mathrm{CDCl}_{3}\right) \delta$ (ppm): 0.65

Table I. ${ }^{13} \mathrm{C}$ chemical shifts of sterols $\mathbf{1 - 6}$ in $\mathrm{CDCl}_{3}$ $\delta[\mathrm{ppm}]$.

\begin{tabular}{rrrrrrr}
\hline C-Atom & \multicolumn{1}{l}{} & \multicolumn{1}{c}{$\mathbf{2}$} & \multicolumn{1}{c}{$\mathbf{3}$} & \multicolumn{1}{c}{$\mathbf{4}$} & \multicolumn{1}{c}{$\mathbf{5}$} & \multicolumn{1}{c}{$\mathbf{6}$} \\
\hline 1 & 36.3 & 36.3 & 36.9 & 36.9 & 37.0 & 37.5 \\
2 & 31.1 & 31.2 & 31.5 & 31.5 & 31.4 & 31.3 \\
3 & 70.4 & 70.5 & 71.4 & 71.4 & 71.3 & 71.3 \\
4 & 41.8 & 41.8 & 41.7 & 41.7 & 42.0 & 42.0 \\
5 & 165.4 & 165.2 & 143.5 & 143.4 & 146.2 & 146.2 \\
6 & 126.0 & 126.1 & 125.5 & 125.4 & 123.9 & 123.8 \\
7 & 202.4 & 202.4 & 73.3 & 73.3 & 65.4 & 65.3 \\
8 & 45.4 & 45.4 & 40.8 & 40.9 & 37.5 & 37.5 \\
9 & 49.9 & 50.0 & 48.3 & 48.2 & 42.3 & 42.2 \\
10 & 38.3 & 38.3 & 36.4 & 36.4 & 37.5 & 37.4 \\
11 & 21.2 & 21.2 & 21.1 & 21.1 & 20.7 & 20.7 \\
12 & 38.7 & 38.7 & 39.6 & 39.5 & 39.2 & 39.2 \\
13 & 43.1 & 43.1 & 42.9 & 42.9 & 42.1 & 42.1 \\
14 & 49.9 & 49.9 & 55.4 & 55.4 & 49.4 & 49.4 \\
15 & 26.3 & 26.3 & 26.4 & 26.4 & 24.3 & 24.3 \\
16 & 28.5 & 28.5 & 28.5 & 28.5 & 28.3 & 28.2 \\
17 & 54.8 & 54.8 & 56.0 & 55.9 & 55.7 & 55.8 \\
18 & 11.9 & 12.0 & 11.8 & 11.8 & 11.6 & 11.6 \\
19 & 17.3 & 17.2 & 19.1 & 19.1 & 18.2 & 18.2 \\
20 & 36.0 & 35.7 & 36.1 & 35.7 & 36.1 & 35.7 \\
21 & 18.9 & 18.9 & 18.8 & 18.7 & 18.8 & 18.7 \\
22 & 33.9 & 36.2 & 34.0 & 36.2 & 33.9 & 36.1 \\
23 & 26.1 & 23.8 & 26.1 & 23.8 & 26.0 & 23.7 \\
24 & 45.8 & 39.5 & 45.8 & 39.5 & 45.9 & 39.5 \\
25 & 29.1 & 28.0 & 29.2 & 28.0 & 29.2 & 28.0 \\
26 & 19.0 & 22.5 & 19.0 & 22.5 & 19.0 & 22.5 \\
27 & 19.8 & 22.8 & 19.9 & 22.8 & 19.8 & 22.8 \\
28 & 23.0 & & 23.1 & & 23.1 & \\
29 & 12.0 & & 12.0 & & 12.0 & \\
\hline & & & & & &
\end{tabular}

(3H, s, H-18), $0.83(3 \mathrm{H}, \mathrm{d}, J=6.6 \mathrm{~Hz}, \mathrm{H}-26), 0.84$ $(3 \mathrm{H}, \mathrm{d}, J=6.6 \mathrm{~Hz}, \mathrm{H}-27), 0.89(3 \mathrm{H}, \mathrm{d}, J=6.5 \mathrm{~Hz}$, $\mathrm{H}-21), 1.17(3 \mathrm{H}, \mathrm{s}, \mathrm{H}-19), 2.20(1 \mathrm{H}, \mathrm{dd}, J=$ $10.1 \mathrm{~Hz}, \mathrm{H}-8), 3.64(1 \mathrm{H}, \mathrm{m}, \mathrm{H}-3 \alpha), 5.66(1 \mathrm{H}, \mathrm{d}, J=$ $1.5 \mathrm{~Hz}, \mathrm{H}-6) ;{ }^{13} \mathrm{C}$ NMR: see Table I.

Stigmast-5-ene-3 $\beta, 7 \beta$-diol (3)

$\mathrm{R}_{\mathrm{f}}$ 0.29; m.p. $169-172{ }^{\circ} \mathrm{C}$; IR $v_{\max } \mathrm{CHCl}_{3} \mathrm{~cm}^{-1}$ : $3607(\mathrm{OH}) ; \mathrm{MS} 70 \mathrm{eV} \mathrm{m} / z$ (rel. int): $412\left(\mathrm{M}^{+}-\mathrm{H}_{2} \mathrm{O}\right.$, 100); ${ }^{1} \mathrm{H}$ NMR $\left(\mathrm{CDCl}_{3}\right) \delta(\mathrm{ppm}): 0.67(3 \mathrm{H}, \mathrm{s}, \mathrm{H}-$ 18), $0.79(3 \mathrm{H}, \mathrm{d}, J=6.6 \mathrm{~Hz}, \mathrm{H}-26), 0.81(3 \mathrm{H}, \mathrm{d}, J=$ $6.6 \mathrm{~Hz}, \mathrm{H}-27), 0.82(3 \mathrm{H}, \mathrm{m}, \mathrm{H}-29), 0.90(3 \mathrm{H}, \mathrm{d}, J=$ $6.4 \mathrm{~Hz}, \mathrm{H}-21), 1.02(3 \mathrm{H}, \mathrm{s}, \mathrm{H}-19), 1.35(1 \mathrm{H}, \mathrm{m}$, $\mathrm{H}-8), 3.52$ (1H, m, H-3 $\alpha), 3.83$ (1H, m, H-7 $\alpha), 5.26$ $(1 \mathrm{H}, \mathrm{d}, J=1.6 \mathrm{~Hz}, \mathrm{H}-6) ;{ }^{13} \mathrm{C}$ NMR: see Table I.

Cholest-5-ene-3 $\beta, 7 \beta$-diol (4)

$\mathrm{R}_{\mathrm{f}}$ 0.28; m.p. $175{ }^{\circ} \mathrm{C}$; ref. (Kumar et al., 1987) m.p. $176-178{ }^{\circ} \mathrm{C}$; IR $v_{\max } \mathrm{CHCl}_{3} \mathrm{~cm}^{-1}: 3605(\mathrm{OH})$; MS $70 \mathrm{eV} \mathrm{m} / z$ (rel. int.): $384\left(\mathrm{M}^{+}-\mathrm{H}_{2} \mathrm{O}, 100\right) ;{ }^{1} \mathrm{H}$ NMR $\left(\mathrm{CDCl}_{3}\right) \delta(\mathrm{ppm}): 0.67(3 \mathrm{H}, \mathrm{s}, \mathrm{H}-18), 0.85$ $(6 \mathrm{H}, \mathrm{d}, J=6.6 \mathrm{~Hz}, \mathrm{H}-26,27), 0.99(3 \mathrm{H}, \mathrm{d}, J=$ $6.9 \mathrm{~Hz}, \mathrm{H}-21), 1.05(3 \mathrm{H}, \mathrm{s}, \mathrm{H}-19), 1.38(1 \mathrm{H}, \mathrm{m}$, $\mathrm{H}-8), 3.52(1 \mathrm{H}, \mathrm{m}, \mathrm{H}-3 \alpha), 3.82(1 \mathrm{H}, \mathrm{m}, \mathrm{H}-7 \alpha), 5.27$ $(1 \mathrm{H}, \mathrm{s}, \mathrm{H}-6) ;{ }^{13} \mathrm{C}$ NMR: see Table I.

\section{Stigmast-5-ene-3 $\beta, 7 \alpha$-diol (5)}

$\mathrm{R}_{\mathrm{f}}$ 0.22; m.p. $198-200^{\circ} \mathrm{C}$; ref. (Fukuyama et al., 1988) m.p. 202-204 ${ }^{\circ} \mathrm{C}$; IR $v_{\max } \mathrm{CHCl}_{3} \mathrm{~cm}^{-1}$ : 3605(OH); MS $70 \mathrm{eV} \mathrm{m} / z$ (rel. int.): $412\left(\mathrm{M}^{+}-\mathrm{H}_{2} \mathrm{O}\right.$, 100); ${ }^{1} \mathrm{H} \mathrm{NMR}\left(\mathrm{CDCl}_{3}\right) \delta(\mathrm{ppm}): 0.67(3 \mathrm{H}, \mathrm{s}$, $\mathrm{H}-18), 0.79$ (3H, d, $J=6.4 \mathrm{~Hz}, \mathrm{H}-26), 0.81(3 \mathrm{H}, \mathrm{d}$, $J=6.5 \mathrm{~Hz}, \mathrm{H}-27), 0.83$ (3H, m, H-29), 0.91 (3H, d, $J=6.4 \mathrm{~Hz}, \mathrm{H}-21), 0.97(3 \mathrm{H}, \mathrm{s}, \mathrm{H}-19), 1.46(1 \mathrm{H}, \mathrm{m}$,

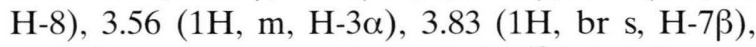
$5.58(1 \mathrm{H}, \mathrm{d}, J=4.1 \mathrm{~Hz}, \mathrm{H}-6) ;{ }^{13} \mathrm{C} \mathrm{NMR}$ : see Table I.

\section{Cholest-5-ene-3 $\beta, 7 \alpha$-diol (6)}

Rf 0.22; m.p. $183-184{ }^{\circ} \mathrm{C}$; ref. (Kumar et al., 1987) m.p. $184-186{ }^{\circ} \mathrm{C}$; IR $v_{\max } \mathrm{CHCl}_{3} \mathrm{~cm}^{-1}$ : 3607(OH); MS $70 \mathrm{eV} \mathrm{m} / z$ (rel. int.): 384 $\left(\mathrm{M}^{+}-\mathrm{H}_{2} \mathrm{O}\right) ;{ }^{1} \mathrm{H}$ NMR $\left(\mathrm{CDCl}_{3}\right) \delta(\mathrm{ppm}): 0.65(3 \mathrm{H}$, s, H-18), $0.83(3 \mathrm{H}, \mathrm{d}, J=6.6 \mathrm{~Hz}, \mathrm{H}-26), 0.84(3 \mathrm{H}$, $\mathrm{d}, J=6.6 \mathrm{~Hz}, \mathrm{H}-27), 0.89(3 \mathrm{H}, \mathrm{d}, J=6.5 \mathrm{~Hz}$, H-21), 0.96 (3H, s, H-19), 1.44 (1H, m, H-8), 3.55 $(1 \mathrm{H}, \mathrm{m}, \mathrm{H}-3 \alpha), 3.82(1 \mathrm{H}$, br s, H-7 $\beta), 5.57(1 \mathrm{H}, \mathrm{d}$, $J=5.3 \mathrm{~Hz}, \mathrm{H}-6) ;{ }^{13} \mathrm{C}$ NMR: see Table I. 


\section{Results and Discussion}

The sterols $\mathbf{1}, \mathbf{3}$, and $\mathbf{5}$ occur in the roots of Hordeum vulgare L. cv. 'Xenia' and $H$. vulgare $\mathrm{L}$. cv. 'Bigo' in a concentration of $1-34 \mu \mathrm{g} / \mathrm{g}$ fresh weight. After spraying the primary leaves of barley (H. vulgare L. cv. 'Abed Binder' with one of the sterols $\mathbf{1}, \mathbf{3}$, and $\mathbf{5}$ induced resistance toward Puccinia striiformis could be detected (Seifert et al., unpublished results). On the basis of these findings the sterols $\mathbf{1}, \mathbf{3}, \mathbf{5}$ and the analog compounds of cholesterol 2, 4, 6 were synthesized (Schabdach, 1992) and tested for resistance inducing activities. The synthesis (Kumar et al., 1987) was realized as follows: Treatment of $\beta$-sitosterylbenzoate and cholesterylbenzoate with ten molar equivalents of $\mathrm{CrO}_{3} / 3,5$-dimethylpyrazole, prepared in situ at $-20{ }^{\circ} \mathrm{C}$, resulted in the corresponding ketones (yields 69-71\%), which were deprotected with $0.1 \mathrm{~m}$ solution of $\mathrm{NaOMe}$ to give

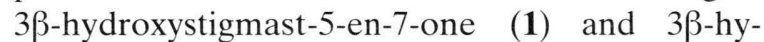
droxycholest-5-en-7-one (2) (yields $80-81 \%$ ). The reduction of 7 -keto- $\beta$-sitosterylbenzoate and 7-ketocholesterylbenzoate either with $\mathrm{NaBH}_{4}$ in the presence of $\mathrm{CeCl}_{3}$ in $\mathrm{THF} / \mathrm{MeOH}$ (2:1) afforded the $7 \beta$-hxdroxylated compounds (yields $97-98 \%)$ or with $\mathrm{LiB}\left[\mathrm{CHCH}_{3}\left(\mathrm{C}_{2} \mathrm{H}_{5}\right)\right]_{3} \mathrm{H}$ (LSelectride) in THF the $7 \alpha$-hydroxylated compounds (yields 60-62\%). Deprotection of the $7 \beta$-hydroxy- and the $7 \alpha$-hydroxysterylbenzoates with $0.1 \mathrm{M}$ solution of $\mathrm{NaOMe}$ gave stigmast-

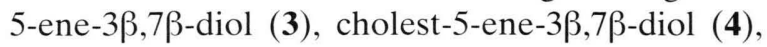
stigmast-5-ene-3 $\beta, 7 \alpha$-diol (5), and cholest-5-ene$3 \beta, 7 \alpha$-diol (6) (yields $89-91 \%$ ). The assignments of the ${ }^{1} \mathrm{H}$ - and ${ }^{13} \mathrm{C}$ NMR data for 1-6 were based on ${ }^{1} \mathrm{H}-,{ }^{1} \mathrm{H},{ }^{1} \mathrm{H}$ COSY-, ${ }^{13} \mathrm{C}-,{ }^{13} \mathrm{C}$ APT-, and ${ }^{1} \mathrm{H},{ }^{13} \mathrm{C}$ COSY-experiments. According to ${ }^{13} \mathrm{C}$ APT and ${ }^{1} \mathrm{H},{ }^{13} \mathrm{C}$ COSY experiments of $\mathbf{3}$ and $\mathbf{5}$ the assignments of the signals C-8, C-12, C-13, C-14, C-17, C-23, C-25, 3 and C-21, C-26, 5 (Chaurasia and Wichtl, 1987) have to be interchanged.

Potential antifungal activities of the sterol derivatives 1-6 were examined in in-vitro tests proving the effects of the compounds on mycelium growth of the pertotrophic fungus Cochliobolus sativus and on spore germination and germ tube

Table II. Effect of 7-oxo- and 7-hydroxysterols 1-6 $\left(10^{-4} \mathrm{~mol} / \mathrm{l}\right.$ in $1 \%$ aqu. ethanol) applied 2 days before challenge inoculation on the infection density of rust fungi on primary leaves of barley cv. 'Mammut' and wheat cv. 'Astron' (means based on 30 measurements per treatment in triplate experiments).

\begin{tabular}{|c|c|c|}
\hline \multirow[b]{2}{*}{ Treatment } & \multicolumn{2}{|c|}{ Barley/Puccinia hordei } \\
\hline & $\begin{array}{l}\text { Number of } \\
\text { infection sites }\end{array}$ & $\begin{array}{l}\% \text { Reduction }{ }^{\mathrm{a}} \text { in } \\
\text { infection sites }\end{array}$ \\
\hline $1 \%$ aqu. ethanol & \multicolumn{2}{|l|}{$64( \pm 14)^{b}$} \\
\hline 3ß-Hydroxystigmast-5-en-7-one (1) & \multicolumn{2}{|c|}{$52( \pm 13) \quad 19$} \\
\hline $3 \beta$-Hydroxycholest-5-en-7-one (2) & \multicolumn{2}{|c|}{$53( \pm 14) \quad 17$} \\
\hline Stigmast-5-ene-3 $\beta, 7 \beta$-diol (3) & \multicolumn{2}{|l|}{$34 *( \pm 7)$} \\
\hline 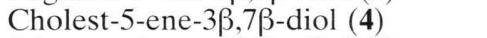 & \multicolumn{2}{|l|}{$44 *( \pm 8)$} \\
\hline Stigmast-5-ene-3 $\beta, 7 \alpha$-diol (5) & \multicolumn{2}{|l|}{$36 *( \pm 7)$} \\
\hline Cholest-5-ene-3 $\beta, 7 \alpha$-diol (6) & \multicolumn{2}{|l|}{$35 *( \pm 6)$} \\
\hline \multirow[b]{2}{*}{ Treatment } & \multicolumn{2}{|c|}{ Wheat/Puccinia striiformis } \\
\hline & $\begin{array}{l}\text { Number of } \\
\text { infection sites }\end{array}$ & $\begin{array}{l}\% \text { Reduction }{ }^{\mathrm{a}} \text { in } \\
\text { infection sites }\end{array}$ \\
\hline $1 \%$ aqu. ethanol & $82( \pm 19)^{\mathrm{b}}$ & \\
\hline $3 \beta$-Hydroxystigmast-5-en-7-one (1) & $69( \pm 14)$ & 16 \\
\hline $3 \beta$-Hydroxycholest-5-en-7-one (2) & $71 \quad( \pm 12)$ & 13 \\
\hline Stigmast-5-ene-3 $\beta, 7 \beta$-diol (3) & $48 *( \pm 10)$ & 42 \\
\hline Cholest-5-ene-3 $\beta, 7 \beta$-diol (4) & $50 *( \pm 6)$ & 39 \\
\hline Stigmast-5-ene-3 $\beta, 7 \alpha$-diol (5) & $42 *( \pm 7)$ & 49 \\
\hline 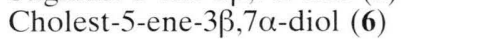 & $42 *( \pm 8)$ & 49 \\
\hline
\end{tabular}


elongation of the biotrophic fungi Erysiphe graminis f. sp. hordei, E. graminis f. sp. tritici, Puccinia hordei and $P$. striiformis by the method described in Materials and Methods. Non of the sterols inhibited colony growth of Cochliobolus sativus in the agar diffusion tests. Neither germination nor germ tube elongation of the biotrophics were affected by the applicated concentrations of the sterols compared to the controls, and no morphological alterations of the germ tubes were observed.

Despite the absence of observable toxic effects on fungal development in vitro, the colony densities of P. hordei on barley plants and of Puccinia striiformis on wheat plants were significantly reduced up to $49 \%$ on plants challenge inoculated 2 days after application of the sterol derivatives 3-6, but only slightly reduced after treatments with 1 and $\mathbf{2}$ (Table II).

Plants challenged immediately after sterol derivatives application were not protected. The necessity of a time interval indicate that changes in the metabolism of the host plants caused the reduced infection density of the plants. Therefore the involvement of a mode of action as described for tricyclazole which has no apparent effect on spore germination but preventing penetration of the fungus Pyricularia oryzae by inhibiting melanization within the appressoria formed only on the plant surface seems unlikely (Peterson, 1990). The degree of protection depended on the dosage of the applicated sterol derivatives and on the frequency of application. Plants treated one time with $10^{-6}$ and $10^{-9} \mathrm{~mol} / \mathrm{l}$ sterol derivative solutions were not protected. Both, barley and wheat plants showed no enhanced resistance toward Erysiphe graminis as well as barley toward Cochliobolus sativus after application of the sterols. These differences in the efficacy of protection could due to differences in the developmental pattern of the fungi. In contrast to Cochliobolus sativus and Ery- siphe graminis which infect their host plant directly through the cuticule, the rust fungi develop a series of complex infection structures to infect the leaf parenchym. These development stages include the formation of appressoria on stomata, and in the intercellular space the formation of the substomal vesicle, infection hypha and haustorial mother cells before haustoria are established within the host cells (Mendgen and Deising, 1993). Possibly, the sterol derivatives activate selectively defense mechanisms of the plants which impaire the development or differentiation of these specific structures. Changes in the morphology or chemistry of the cuticula preventing the formation of appressoria on stomata may lead the fungus astray. In non-host plants rust fungi growth stopped during formation of the substomatal vesicle or of the haustorial mother cell (Fink et al., 1990). More histological studies are required to elucidate the mode of action of this new group of chemicals broading the spectrum of substances capable to induce resistance against plant diseases.

Small quantities of the sterol compounds were required to induce resistance. The results indicate that $7 \alpha$ - and $7 \beta$-epimers induce more efficiently plant disease resistance compared to the corresponding 7-keto derivatives. This could result from differences in the uptake or recognition due to the binding to components of the cell wall matrix, plasmalemma or cytoplasmic receptors. Cohen et al. (1994) studied the effects of $\alpha, \beta$ and $\gamma$-isomers of aminobutrytic acid on late blight development (Phytophthora infestans) in tomato plants. They also reported an isomer specific induction of resistance. Precise experiments on the uptake and translocation of the bioactive sterol compounds in barley will be the aim of further investigations.

\section{Acknowledgements}

We thank the Deutsche Forschungsgemeinschaft for financial support (Grant SE 595/2-1). 
Chaurasia N. and Wichtl M. (1987), Sterols and steryl glycosides from Urtica dioica. J. Nat. Prod. 50, $881-885$.

Chester K.S. (1933), The problem of aquired pysiological immunity in plants. Q. Rev. Biol. 8, 129, 275.

Chicoye E., Powrie W.D., and Fennema O. (1968), Synthesis, purification and characterization of 7-ketocholesterol and epimeric 7-hydroxycholesterols. Lipids 3 , $551-556$.

Cohen Y., Gisi U., and Mosinger E. (1991), Systemic resistance of potato plants against Phytophthora infestans induced by unsaturated fatty acids. Physiol. Mol. Plant. Pathol. 38, 255-263.

Cohen Y., Nidermann T., Mosinger E., and Fluhr R. (1994), $\beta$-Aminobutyric acid induces the accumulation of pathogenesis-related proteins in tomato (Lycopersion esculentum L.) plants and resistance to late blight infection caused by Phytophthora infestans. Plant. Physiol. 104, 59-66.

Doubrava N., Dean R., and Kuc J. (1988), Induction of systemic resistance to anthracnose caused by Colletotrichum lagenarium in cucumber by oxalate and extracts from spinach and rhubarb leaves. Physiol. Mol. Plant Pathol. 33, 69-79.

Fink W., Liefland M., and Mendgen K. (1990), Comparison of various stress responses in oat in compatible and nonhost resistant interactions with rust fungi. Physiol. Mol. Plant Pathol. 37, 309-321.

Fukuyama Y., Nakano Y., Pei-Wu G., Rui W., Sumitomo J., Jinxian B., and Nakagama K. (1988), In vitro fibrinolytic phytosterols isolated from the roots of Spatholobus suberetus. Planta Medica 54, 534-536.

Hammerschmidt R. (1993), The nature and generation of systemic signals induced by pathogens, athropod herbivores, and wounds. Adv. Plant Pathol. 10, $307-337$.

Herger G., Klingauf F.M.D., Pommer E.H., and Scherer M. (1988), Die Wirkung von Auszügen aus dem Sachalin-Staudenknöterich, Reynoutria sachalinensis (F. Schmidt) Nakai, gegen Pilzkrankheiten, insbesondere Mehltaupilze. Nachr. Bl. dt. Pflschutzdienst 40 , $56-60$.

Horsfall J.C. and Cowling E.B. eds. (1980), Plant disease: An advanced treatis. Vol 5. How plants defend themselves. Academic Press, New York.

Kuc J. (1987), Plant immunization and its applicability for disease control. In: Chet I. (ed.), Innovative approaches to plant disease control. Wiley and Sons, New York, 255-273.
Kumar V., Amann A., and Luu B. (1987), Stereospecific synthesis of $7 \beta$ - and $7 \alpha$-hydroxycholesterols. Synth. Commun. 17, 1279-1286.

Kunz W., Staub T., Métraux J.P., Hoeherle K., Nyfeler R., and Ahl P. (1988), Europ. Patent, 026875.

Mendgen K. and Deising H. (1993), Infection structures of fungal plant pathogens - a cytological and physiological evaluation. New. Phytol. 124, 193-213.

Mills P. and Wood R. (1984), The effects of polyacrylic acid, acetylsalicylic acid, and salicylic acid on the resistance of cucumber to Colletotrichum lagenarium. Phytopath. Z. 11, 209-216.

Peterson Z.G. (1990), Tricylazole for control of Pyricularia oryzae on rice: The relationship of the mode of action and disease occurrence and developement. In: Grayson T., Green M.B., and Copping Z.G. (eds.), Pestmanagement in rice. Elsevier Applied Sciences, London, New York.

Reiss E. (1986), Senkung des Gelbrostbefalls anfälliger Gerstenpflanzen nach Applikation von Infiltraten aus gelbrostinfizierten, resistenten Gerstenblättern. Phytopath. Z. 111, 209-216.

Schabdach H. (1992), Diplomarbeit. Universität Bayreuth.

Schönbeck F., Dehne H.W., and Beicht W. (1981), Untersuchungen zur Aktivierung unspezifischer Resitenzmechanismen in Pflanzen. Z. Pflkrankh. Pflschutz 87, 654-666.

Schönbeck F., Steiner U., and Kraska T. (1993), Induzierte Resistenz: Kriterien, Mechanismen, Anwendungen und Bewertung. Z. Pflkrankh. Pflschutz 100, $541-557$

Sekizawa Y. and Mase S. (1981), Mode of controlling action of probeconazole against rice blast disease with reference to the induced resistance mechanism in rice plants. J. Pestic. Sci. 6, 91-94.

Sequeira L. (1983), Mechanisms of induced resistance in plants. Annu. Rev. Microbiol. 37, 51-79.

Steiner U. and Schönbeck F. (1993), Induced resistance as a means of plant disease control. In: Altman J. (ed.), Pesticide interactions in crop production: Beneficial and deleterious effects. CRC Press, Inc., $495-512$. 